\title{
Hydrological surveys of the Lake Peschanoe and the Sernovodsky isthmus of Kunashir island (Greater Kuril chain)
}

\author{
Mikhail Y. Grishchenko, ${ }^{1,2,}$, Vasiliy I. Krylenko ${ }^{1}$, Viktoria T. Ozhgikhina ${ }^{1}$, Artyom V. \\ Gorbarenko $^{1}$ \\ ${ }^{1}$ M.V. Lomonosov MSU, Faculty of Geography, 119991, Moscow, Russia \\ ${ }^{2}$ State nature reserve "Kurilskiy", 694500, Yuzhno-Kurilsk, Russia
}

\begin{abstract}
The article is devoted to the study of the largest lake of the island of Kunashir - the lake Peschanoe (means Sandy) - and the adjacent sections of the coast of the Sea of Okhotsk. Despite its considerable size and relatively easy transport accessibility, the lake still remains relatively poorly explored. The topography of its bottom was studied, in particular, the maximum depth of the lake $(23 \mathrm{~m})$ was measured; hydrological and hydrobiological surveys of the lake were conducted; the influence of the wind on the intensity of mixing of the lake's waters was assessed; lagoon origin of the lake was proven; the coastline of the Sea of Okhotsk in the vicinity of the lake was examined. It was revealed that the lake lost connection with the sea long enough so that there are no signs of salt in its water, but not so long enough that it stopped being inhabited by mesohalobiotic crustaceans. The influence of typhoons on the mixing of the lake's waters is very great that is surprising for such a large lake. This is facilitated by its geographical position on the Sernovodsky isthmus, due to which it is open to both winds blowing from east and west.
\end{abstract}

\section{Introduction}

Due to its remote location and peculiar natural conditions, Kunashir is still a poorly explored island. As a zone of active development of modern volcanism, the Kuril Islands (and Kunashir, in particular) are relatively well studied in geological and geomorphological terms. Geological structure and geomorphology of the island were generally described in the middle of the second half of the last century in the works of G.S. Gorshkov [1], E.K. Markhinin [2, 3], I.V. Melekestsev [4, 5] and others. In addition, there are a number of works on the structure and development of the island's coastal relief $[6,7]$, as well as on some paleogeographical issues [8-10]. These works describe the nature of the hydrological objects. There is a range of works devoted to individual hydrological objects, in particular, to volcanic lakes $[11,12]$. At the same time, there are still no generalizing works devoted to the hydrological issues of Kunashir. Researchers also pay little attention to major

\footnotetext{
*Corresponding author: m.gri@geogr.msu.ru
} 
hydrological objects that are not characterized by pronounced confinement to volcanic systems, such as the lake Peschanoe.

The purpose of the adjustment work is to fill the gap in the study of the largest lake on the island as a hydrological object. The Sernovodsky Isthmus, most of which is occupied by Lake Peschanoe, is an interesting natural object due to the peculiarities of its geomorphological structure. The study of these objects is of interest not only from a scientific, but also from an ecological and educational point of view, since the territory belongs to the Kurilskiy State Nature Reserve, and here the possibility of organizing a full-fledged ecological-tourist route is being considered.

Kunashir is the southernmost island of the Greater Kuril chain and the fourth largest area of the Kuril islands. The island is washed by the sea of Okhotsk from the west and by the Pacific ocean from the east. Kunashir is separated from the Japanese island of Hokkaido by the Kunashir and Izmeny straits, from the Iturup island by the Catherine strait, and from the islands of the Lesser Kuril ridge by the South Kuril strait. The relief of the island is predominantly low-mountain; in some areas, it is mid-mountain, hilly, or flat; the volcanic origin of the main forms is clearly expressed. The island is formed by four volcanic masses, which are connected by low-lying isthmuses. The highest point of the island is the Tyatya volcano, $1819 \mathrm{~m}$ high. The coasts of the island are mostly rocky, steep with narrow rocky beaches, less often gentle with sand dunes and sandy beaches; the coastline is very slightly indented. The rivers of the island rise mostly in mountains; the valleys are deeply incised; rifts and waterfalls are quite common. Watercourses are characterized by a pronounced flood regime; discharge increases in the period of typhoons lasting from July to October inclusive. The lakes are of lagoon and volcanic origin. Kunashir's climate is oceanic, rather humid. The annual rainfall in Yuzhno-Kurilsk is up to $1300 \mathrm{~m}$, while the interannual variability in rainfall is very high. Summer is cool, rainy, with frequent fogs, south and south-east winds. Typhoons and windstorms are rather common in summer and autumn. Winter snowfalls are alternated with thaws; winds blow mainly from the north and northwest.

The lake Peschanoe is the largest lake of the island. It is located on the Sernovodsky (means Sulphur Water) isthmus, dividing the volcanic masses of the volcanoes of Mendeleev and Golovnin and representing a lowland plain, most of which is occupied by the basin of the lake. Its length is $4.5 \mathrm{~km}$; width is $2.4 \mathrm{~km}$; an area is $7.14 \mathrm{~km} 2$; the average depth is $4.2 \mathrm{~m}$; the maximum depth is $23 \mathrm{~m}$. The Pacific sector of the Sernovodsky isthmus is occupied by a swampy red thin forest; the dune field, very interesting from a geomorphological point of view. It is confined to the sea of Okhotsk; it is composed of polymictic sands (to which, probably, the lake owes its name) formed, apparently, as a result of wind activity. These characteristic features of the geosystems of the Sernovodsky isthmus are determined by the features of its wind regime - it is a natural channel for air flows from both the south and east, and from the west [13]. The lake lies in the territory of the Kurilsky nature reserve and its conservation zone.

\section{Materials and methods}

Field work on the lake Peschanoe was performed in the period from August 8, 2019 to August 29, 2019. It included installing a water gauging station and monitoring of the water level; bathymetric survey; temperature survey and temperature profiling; selection of hydrobiological samples of benthic organisms from the shallow water of the lake and from surrounding water bodies; study of the coastline of the lake. To measure the temperature and electrical conductivity of the water, the Mark 603 conductometer was used. The water level was monitored using a pole marked every 10 centimeters. The bathymetric survey was 
conducted using Lowrance echo sounder and YSI CastAway CTD probe. Temperature and salinity indicators were also measured using this probe. The coastline of the lake and the coastline of the sea of Okhotsk in the region of the Sernovodsky isthmus from the Znamenka bay to the mouth of the Asin spring were studied.

\section{Results and discussion}

\subsection{Bathymetry}

Based on the results of the bathymetric survey we generated a map of the depths of the lake Peschanoe (fig. 1). It clearly shows that in the central part of the lake there is a deep basin with characteristic depths of approximately 23 meters. To the northwest and southeast of it, the depth of the lake decreases. The depth of the sea of Okhotsk near the shores of Kunashir is approximately $20 \mathrm{~m}$ that reveals that there was a strait between two volcanic massifs on the site of the lake Peschanoe. But due to geomorphological processes, such as the accumulation of sedimentary material on the isthmus from the sea of Okhotsk and from the Pacific ocean, the lake lost connection with the ocean. Therefore, it is a lake of lagoon type. The lake Peschanoe is the remnant of the deepest part of the ancient strait, separated from the sea by enclosures from marine and lagoon sediments.

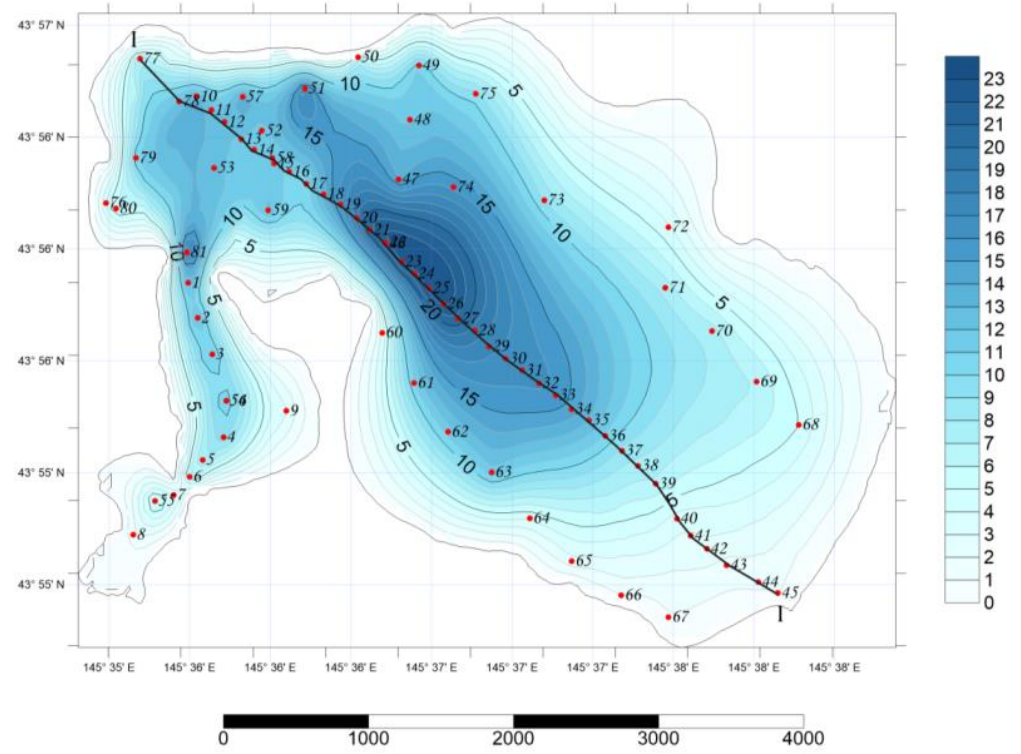

Fig. 1. Bathymetric map of the lake Peschanoe.

\subsection{Salinity}

Further work, namely, measurements of the salinity of the lake's waters, showed that the lake lost connection with the sea a very long time ago, since no signs of sea water were found in it. To determine the exact date of loss of connection with the sea, a series of works should be conducted to study the watercourses flowing into the lake Peschanoe, namely, to calculate their flow rate and to identify their mineralization. Thanks to this information and the materials we have already collected (topography of the lake's bottom), it will be 
possible to calculate the period, during which salt water would have reached the current mineralization values.

\subsection{Temperature}

Over the entire period of studies, we set 81 hydrological stations, each of which measured the depth and temperature distribution over it. In the deepest place $(23 \mathrm{~m})$, we recorded a temperature of $15.8^{\circ} \mathrm{C}$ - one of the lowest temperatures in the observed period. The surface temperature in the shallowest place coincides with the air temperature registered that day $21.8^{\circ} \mathrm{C}$. The most interesting phenomenon is the lens of cold water remaining after the previous large-scale mixing and cooling of water associated with the passage of a typhoon (fig. 2).

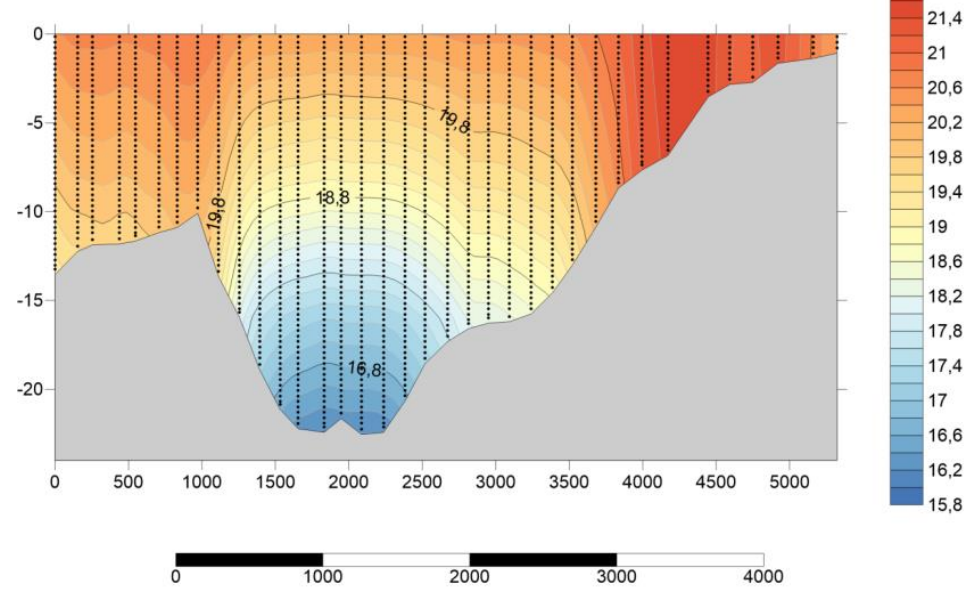

Fig. 2. The distribution of temperature over the depth of the lake Peschanoe, August 11, 2019

The dynamics of water temperature is very pronounced when comparing the temperature distribution over depth before a typhoon, immediately after it, and a few days after it. The longitudinal profile of the lake showed two edges of the lake bottom with a sharp difference in depths: $5 \mathrm{~m}$ and $10 \mathrm{~m}$. Due to this feature, the relief of the lake's bottom, the undulation in days with a calmer wind regime is not intensive enough to mix the water so much. Undulation continues till the first edge (5 meters of depth) with a pronounced isotherm. In the region of this edge, we observed a thermocline. The same phenomenon was observed near the second edge of the lake's bottom $(10 \mathrm{~m})$.

\section{4 Fauna}

The fact that the lake Peschanoye was previously connected to the sea is also confirmed by the composition of its fauna. It consists mainly of mesohalobiotic species of crustaceans, widely represented in reservoirs of the same type on the other islands of the archipelago. We noted five species from four families. Anisogammarus annandalei (Shen, 1954) and $A$. kygi (Derzhavin, 1923) (Anisogammaridae), which practically do not form joint clusters, are common for lakes and for adjacent streams. Among the isospods, we found specific mesohalobiotic Gnorimosphaeroma ovatum (Gurjanova, 1933) (Sphaeromatidae), Neomysis awatschensis misids (Brandt, 1851) (Mysidae), and penaeidae Palaemon 
paucidens (De Haan, 1844) (Palaemonida). But the presence of many brook species in the waters of the lake indicates its strong desalination.

\subsection{Formation of the lake. Sea coast}

The formation of lagoon lakes is generally characteristic of the island. The vast majority of the large lakes of Kunashir are of lagoon origin. The coastline of the island is very dynamic; materials composing the shore are constantly redeposited. Abrasion shores are widespread - steep slopes abruptly terminate near the sea of Okhotsk or the Pacific ocean; narrow rocky beaches are confined at their foot. Sandy beaches are less common. These are rocky benches covered by sand. The coastline is slightly indented, without large bays.

Since the studied section of the coast of the sea of Okhotsk is confined to the low-lying isthmus Sernovodsky, sandy beaches here are more widespread than on the island as a whole (fig. 3), but here can be observed the same patterns. The section from Znamenka bay to the beginning of the ledge of the Znamenka cape is represented by narrow sand and pebble beach and a fairly wide sea terrace. In the area of the Znamenka cape, the coastline acquires a distinct abrasion character, with a large number of boulders; the beach becomes sandy-boulder with rocky outcrops of tuffs and small outcrops of basalts; the width of the beach is reduced to 10 meters; its narrow strip stretches along the sodded dead cliff (fig. 4). Directly on the cape are the Dva Brata (means Two Brothers) kekurs of basalt origin, approximately 15 meters high. Such a nature of the shore is associated with the refraction of sea waves near the capes.

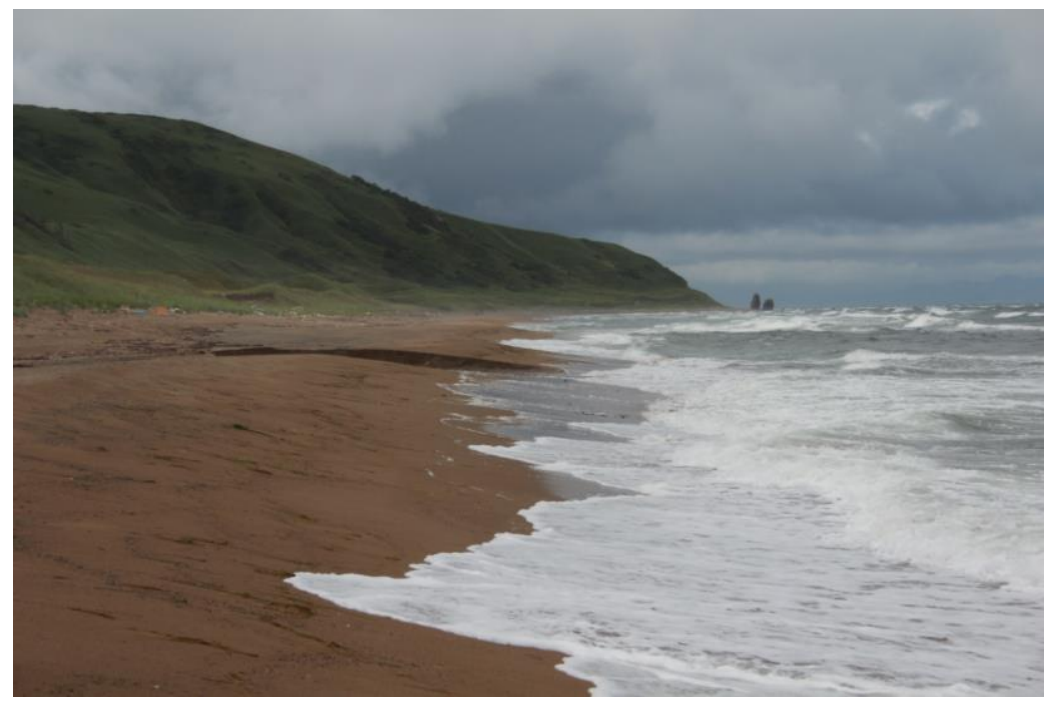

Fig. 3. The sandy beach between the Znamenka cape and the Danilovsky stream mouth. In the background - kekurs Dva Brata. 


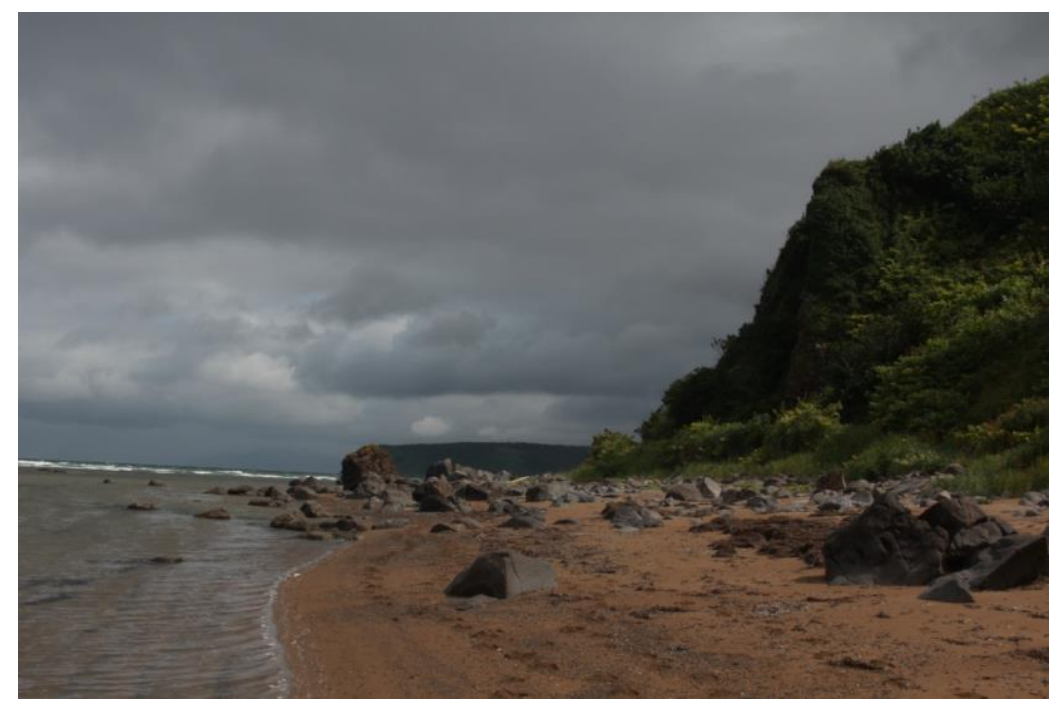

Fig. 4. Rocky beach near the Znamenka cape.

This results in steep waves, and active bank abrasion, whereas sediment is intensively accumulated in the bays with active deposition of the massive material. The accumulative section of the coast lying farther stretches from Cape Znamenka to the mouth of the Danilovsky spring. It is a relatively wide (50-60 meters) sandy beach with an avant-dune up to 2 meters high, turning into a small sea terrace with a width of 100-150 meters followed by bedrock slope. Directly on the Sernovodsky isthmus, the beach retains its width, but after 1st sea terrace starts a dune field (sand dunes) forming a land plot between the sea of Okhotsk and the lake Peschanoe. From the mouth of the Danilovsky spring to the cape Otatomi, the strip of the beach narrows to 10-20 meters; in this place, a large number of lumps are found on the beach. Right at the cape Otatomi, the nature of the coast is similar to the nature of the coast at the cape Znamenka - it becomes stony and narrow. Farther, the beach expands and becomes sandy-boulder; in this place, it is 30 meter wide; the height of the dune is approximately 2 meters; an extensive sea terrace stretches up to 200 meters wide, cut through by the valleys of the Lobanov and Asin springs.

Our study area revealed that the width of the beaches tends to reduce to the capes whereas the widest beaches tend to be confined to the coastal areas south of the capes. Perhaps this is due to the prevailing instability of the northern rhumbs [14]. The considered section of the coast stretches from the southwest to the northeast, so the abrasion force of the waves is directed to the coastline at an angle. This leads to the movement of beachforming sediments in the southern parts of the bays, where they accumulate and form beaches of greater width.

\section{Conclusions}

1. The Lake Peschanoe is the remnant of the deepest part of the ancient strait, separated from the sea by enclosures from marine and lagoon sediments, i.e. this lake is of a lagoon type. It lost connection with the sea for quite a long time, since there are no signs of sea water in it anymore.

2. The fauna of the lake Peschanoe is based on mesohalobiotic species of crustaceans, widely represented in reservoirs of the same type in the Kuril islands. Moreover, the presence of many brook species in the waters of the lake indicates that the rate of its desalination has decreased significantly. 
3. The passage of typhoons over the island of Kunashir leads to very intensive mixing of the lake's waters, which is facilitated by its geographical position on the isthmus Sernovodsky, due to which it is open to both winds blowing from the Pacific ocean and winds blowing from the sea of Okhotsk.

4. In the area from the Znamenka bay to the mouth of the Asin spring, we found a pattern of reducing the width of the beaches to the capes and the confinement of the widest beaches to coastal areas south of the capes.

\section{References}

1. G.S. Gorshkov, Volcanism of the Kuril island arc. (Nauka, Moscow, 1967) (in Russian).

2. Y.K. Markhinin, Volcanism of Kamchatka and the Kuril Islands. Tr. Labor. vulkanol. AN SSSR, Vol. 17, 64-155 (Publishing house of the Academy of Sciences of the USSR, Moscow, 1959) (in Russian)

3. Y.K. Markhinin, Magmatism and the relationship of minerals, (Gosgeoltekhizdat, Moscow, 1960) (in Russian)

4. I.V. Melekestsev, Kamchatka, Kuril and Commander islands, 337-344 (Nedra, Moscow, 1974) (in Russian)

5. I.V. Melekestsev, O.A. Braytseva, L.D. Sulerzhitskiy, N.N. Kozhemyaka, N.V.Ogorodov, I.A. Yegorova, Y.G. Lupikina, Volcanism and the depths of the Earth, 68-74 (Nauka, Moscow, 1971) (in Russian)

6. A.P. Kulakov, Quaternary coastlines of the Sea of Okhotsk and the Sea of Japan, (Nauka (Siberia), Novosibirsk, 1973) (in Russian)

7. A.M. Korotkiy, N.G. Razzhigayeva, L.M. Mokhova, L.A. Ganzey, T.A. Grebennikova, V.B. Bazarova, Tikhookeanskaya geologiya, 15(1), 53-59 (1996) (in Russian)

8. A.M. Korotkiy, N.G. Razzhigayeva, T.A. Grebennikova, L.A. Ganzey, L.M. Mokhova, V.B. Bazarova, L.D. Sulerzhitskiy, K.A. Lutayenko, Tikhookeanskaya geologiya, 18 (1), 25-40 (1999) (in Russian)

9. N.G. Razzhigayeva, T.A. Grebennikova, V.B. Bazarova, L.D. Sulerzhitskiy, L.A.Ganzey, V.S. Pushkar', A.V. Chernov, Tikhookeanskaya geologiya, 19(2), 73-86 (2000) (in Russian)

10. N.G. Razzhigayeva, L.A. Ganzey, Sedimentation conditions of island territories in the Pleistocene-Holocene (Dal'nauka, Vladivostok, 2006) (in Russian)

11. M.Y.Grishchenko, E.V.Belozyorov, M.I. Karashova, E.D. Kornilova, N.A. Maksakov, A.V. Nepomnyashchaya, D.V. Petrov, Geoinformatsionnoye kartografirovaniye $v$ regionakh Rossii: materialy $X$ Vserossiyskoy nauchno-prakticheskoy konferentsii (Voronezh, 14-16 noyabrya 2018 g.), 33-38 (Nauchnaya kniga, Voronezh, 2018) (In Russian)

12. D.N. Kozlov, R.V. Zharkov, Vestnik KRAUNTs, 14(2), 30-35 (2009) (In Russian)

13. L.M.Alekseyeva, V.V. Belashko, G.A.Voronov, et al., South Kuril islands (naturaleconomic essay) (Yuzhno-Sakhalinsk, 1992) (In Russian) 